\title{
Unconscionability and proprietary estoppel remedies
}

\author{
ANDREW ROBERTSON*
}

\section{A. Introduction}

In recent years both courts and scholars have embraced the idea that the notion of unconscionability has a role to play in determining the appropriate remedy in proprietary estoppel cases. This means that, in exercising the remedial discretion it exercises in giving effect to proprietary estoppel, a court should consider what remedy is required in the circumstances to assuage the conscience of the representor. ${ }^{1}$ If the fundamental concern of proprietary estoppel is to prevent or redress unconscionable conduct, then it stands to reason that the remedial discretion should be informed by a consideration of what the representor's conscience, properly informed, would require.' There are three different ways in which unconscionability might be taken into account in the framing of relief. First, the remedy could reflect the reprehensibility of the representor's conduct (the 'reprehensibility' approach). On this view, the more reprehensible the conduct, the more extensive the remedy that is needed to correct the representor's conscience. Second, the remedy could reflect the extent of the representor's responsibility for the relying party's predicament (the 'extent of responsibility' approach). Under this approach, the more significant the role played by the representor in inducing the relevant assumption and failing to correct it, the more extensive the remedy that will be required

\footnotetext{
* Some of the ideas discussed in this chapterhave their origins in a PhD thesis I wrote in the mid-1990s under the co-supervision of Michael Bryan on 'The Reliance Basis of Estoppels by Conduct'. Michael was a great teacher, extremely kind and encouraging supervisor and has been a generous and supportive colleague over the past ten years at Melbourne Law School. I am delighted to have the opportunity to join with the other contributors to this collection in paying tribute to him.

1 Throughout this chapter, the party against whom an estoppel is claimed will be referred to as the 'representor' and the party claiming the benefit of an estoppel will be referred to as the 'relying party'.
} 
to prevent unconscionable conduct. Third, the exercise of the remedial discretion could involve a broad assessment of what relief, considering all circumstances 'in the round', is necessary to assuage the representor's conscience (the 'in the round' approach). This third approach allows the court to take account of the factors considered under the first two approaches, along with others, such as the financial needs of the parties.

This chapter will examine the way in which each of these approaches operates; and will show that each of the three finds some support in the case law. It will argue, however, that none of the three can be justified in principle. The essence of the argument to be offered is that unconscionability can add nothing to the remedial equation in a proprietary estoppel case beyond identifying the need to protect against reliance loss. The underlying concern to prevent unconscionable conduct justifies the court's concern that the relying party should suffer no harm as a result of the representor's inconsistent conduct, but can require no more than this. Because harm resulting from the relying party's reliance on the representor's conduct is an indispensible ingredient of the variety of unconscionable conduct that underlies proprietary estoppel, the representor's conscience is fully assuaged by a remedy that ensures the relying party suffers no harm as a result of action taken in reliance on the representor's conduct. This view reflects what could be seen as a fourth approach to unconscionability in proprietary estoppel remedies, which is that the only role played by unconscionability in the determination of relief in a proprietary estoppel case is to point to the need to ensure complete protection for the relying party against harm resulting from his or her reliance on the relevant assumption.

\section{B. Reliance, expectations and the dictates of conscience}

In a very well-known statement in Crabb $v$ Arun District Council, ${ }^{2}$ Scarman LJ said that a court considering a proprietary estoppel case has to consider three questions: 'First, is there an equity established? Secondly, what is the extent of the equity, if one is established? And, thirdly, what is the relief appropriate to satisfy the equity?'3 Although scholars sometimes treat the extent of the equity or quantum as an issue that is separate from the form that relief should take, ${ }^{4}$ the courts tend not to do this. Although

2 [1976] Ch 179 (CA) ('Crabb'). . ${ }^{3}$ Ibid 192-3.

4 See eg, B McFarlane, The Structure of Property Law (Hart Publishing, Oxford 2008) ch E4; S Gardner, 'The Remedial Discretion in Proprietary Estoppel: Again' (2006) 122 LQR 492. 
Scarman LJ's dictum is commonly quoted, judges tend to merge the second and third questions. Scarman LJ himself did this in Crabb. Having determined that an equity was established in the circumstances, he then said: 'I turn now to the other two questions - the extent of the equity and the relief needed to satisfy it.' ${ }^{\prime 5}$ The reason for this tendency may be that it is difficult to describe the extent of an equity without using either a firm figure (eg 'the extent of the equity is $\$ 100,000$ ') or a particular form (eg 'the extent of the equity is that the claimant should have the fee simple'). It is commonly very difficult, and unnecesșary, to express the extent of the equity in the form of an amount of money. ${ }^{6}$ To express the equity in the form of particular relief of course answers Scarman LJ's third question as well as his second. This chapter follows the common practice of the courts and treats the extent of the equity and the relief necessary to satisfy it as a single question of remedial discretion: how should an equity arising by way of proprietary estoppel be satisfied?

The central issue in the exercise of the remedial discretion in a proprietary estoppel case concerns the relationship between the protection of the relying party's expectations and his or her actual or potential reliance loss. It is now well established in English and Australian law that the starting point in determining relief when a proprietary estoppel is established is the fulfilment of the relying party's expectations in specie. The relying party's assumptions or expectations are to be made good unless to do so would be: (a) impractical; or (b) unjust to the party against whom the estoppel is claimed.' As to the first qualification, there are several reasons why it might be impractical to fulfil the relying party's expectations: (i) because of uncertainty as to the nature or extent of the interest the relying party expected to receive, ${ }^{8}$ (ii) because the subject property has been disposed of, ${ }^{9}$ (iii) because a clean break between the parties is required, ${ }^{10}$ or (iv) because it would cause injustice to a third party to

5 Crabb (n 2) 199.

6 This is because the extent of the equity depends on the extent of the detriment, and the detriment tends not to be easily quantifiable: see A Robertson, "The Reliance Basis of Proprietary Estoppel Remedies' (2008) 78 Conv 295.

7 Ibid 297. The discussion in this section of the chapter d raws on my analyssis of the case law in that article and two others: 'Reliance and Expectation in Estoppel Remedies' (1998) 18 LS 360; 'Satisfying the Minimum Equity: Equitable Estoppel Remedies after Verwayen' (1996) 20 MULR 805.

${ }^{8}$ Eg Unity Joint Stock Banking Corporation v King (1858) 25 Beav 72, 53 ER 563; Plimmer v Wellington Corporation (1884) 9 App Cas 699 (PC).

9 Eg Wayling v Jones (1995) 69 P \& CR 170.

${ }^{10}$ Eg Burrows v Sharp (1991) 23 HLR 82 (CA); Gillett v Holt [2001] 1 Ch 210 (CA). 
require the representor to transfer the promised interest to the relying party. ${ }^{11}$ Second, and more significantly for the purposes of this chapter, the relying party's prima facie entitlement to receive the promised or expected interest will give way to some lesser remedy where the value of the expected interest is disproportionate to the harm that would be suffered by the relying party as a result of his or her reliance if the relevant assumption was not made good. This is sometimes described as the 'minimum equity' principle: it requires the court to grant the minimum remedy necessary to satisfy the relying party's equity, which means the minimum necessary to protect against reliance-based harm.

This principle can be said to be grounded in the notion of unconscionability or, more particularly, the need to 'avoid relief which [goes] beyond what [is] required for conscientious conduct'. ${ }^{12}$ In a well-known statement in Commonwealth $v$ Verwayen, ${ }^{13}$ Deane J said that:

the prima facie entitlement to relief based upon the assumed state of affairs will be qualified in a case where such relief would exceed what could be justified by the requirements of good conscience and would be unjust to the estopped party. In such a case, relief framed on the basis of the assumed state of affairs represents the outer limits within which the relief appropriate to do justice between the parties should be framed. ${ }^{14}$

This statement of principle leaves open the question of when relief based on the assumed state of affairs will exceed the requirements of good conscience and on what basis it will be considered to do so. Since detriment resulting from reliance is an indispensible ingredient of unconscionable conduct in a proprietary estoppel case, it might be said that a remedy that goes beyond what is necessary to prevent detriment resulting from reliance will exceed the requirements of good conscience. In Waltons Stores (Interstate) Ltd $v$ Maher, ${ }^{15}$ Brennan J said that equitable estoppel was best understood by:

identifying the unconscionable conduct which gives rise to the equity as the leaving of a nother to suffer detriment occasioned by the conduct of the party against whom the equity is raised. Then the object of the principle can be seen to be the avoidance of thatdetriment and the satisfaction of the equity calls for the enforcement of a promise only as a means of avoiding the detriment and only to the extent necessary to achieve that object. ${ }^{16}$

${ }_{11}$ Eg Giumelli v Giumelli (1999) 196CLR 101 (HCA). ${ }^{12}$ Ibid 125.

${ }^{13}$ (1990) 170 CLR 394. ${ }^{14}$ Ibid 445-6. ${ }^{15}$ (1987) 164 CLR 387. ${ }^{16}$ Ibid 427. 
On this view, the notion of unconscionability informs the remedial discretion in proprietary estoppel through the minimum equity or proportionality principle. Since the proportionality principle is now regarded as the 'most essential requirement' in the determination of relief in proprietary estoppel cases, ${ }^{17}$ it is important to take note of the way it operates and the effect it has. The need to ensure proportionality between the remedy and the detriment is now given explicit consideration in almost all cases in which English and Australian courts are required to frame relief to give effect to proprietary estoppel. ${ }^{18}$ In most cases it is found that the only way to satisfy the equity raised by the estoppel is by requiring the representor to make good the expectation, usually in specie but sometimes in monetary form. In some cases this is because the relying party's reliance interest happens to coincide in form or in value with his or her expectation interest. But the principal reason that the application of the proportionality principle does not usually result in the granting of a lesser remedy is because the relying party's reliance loss is typically not readily quantifiable, and so the court cannot be satisfied that it can adequately be prevented by anything less than fulfilment of the relying party's expectations. Where the relying party's reliance loss cannot accurately be quantified then usually the only way to ensure that the relying party does not suffer loss as a result of his or her reliance is to fulfil his or her expectations.

In the majority of cases, therefore, the proportionality principle does not displace the relying party's prima facie entitlement to fulfilment of his or her expectations because the representor is unable to show that complete protection against reliance loss can be achieved in any other way. The proportionality principle does, however, play an important role in shaping proprietary estoppel relief in England and Australia. In a significant minority of cases the court does reach the conclusion that awarding the relying party the expected interest would be disproportionate to his or her reliance loss, and that more limited relief can provide adequate protection against reliance loss. In some cases this is done by way of equitable compensation quantified by reference to the relying party's reliance loss. ${ }^{19}$ In other cases the relying party's reliance loss is disproportionate to the value of the expected interest but cannot accurately be quantified. In

17 Jennings $v$ Rice [2002] EWCA Civ 159, [2003] 1 FCR 501 [36].

${ }_{18}$ Robertson (n 6) 298.

19 Eg Strover v Strover [2005] EWHC 860; Young v Lalic [2006] NSWSC 18; Powell v Benney [2007] EWCA Civ 1283; Repatriation Commission v Tsourounakis [2007] FCAFC 29, (2007) 158 FCR 214, (2007) 239 ALR 491. 
these cases relief is determined on the basis of a 'broad-brush' approach, which yields a monetary or proprietary remedy reflecting neither the full extent of the relying party's expectations nor the precise value of his or her reliance loss. ${ }^{20}$ In still other cases the court is able to grant specific relief - such as the right to occupy property for a limited period - which has the effect of allowing the relying party to resume the position he or she occupied beforetaking action in reliance. ${ }^{21}$

Up to this point the remedial equation in a proprietary estoppel case can be seen as turning on three central questions: first, whether it is possible in practical terms to grant the relying party the interest he or she expected to receive; second, whether to do so would be unjust to the representor because it would go beyond what is necessary to ensure that the relying party suffers no reliance loss; and, third, if so, what is the minimum remedy necessary to achieve that end. We now need to consider the effect on that remedial equation of the unconscionability criterion in its 'reprehensibility', 'extent of responsibility' and 'in the round' formulations.

\section{The 'reprehensibility' approach}

In the Court of Appeal in Cobbe $v$ Yeoman's Row Management Ltd, ${ }^{22}$ Dyson LJ listed 'the degree to which the representor's conduct can properly be said to be unconscionable' as one of the factors to be taken into account in determining 'what relief justice requires to satisfy the equity'. ${ }^{23}$ 'This seems to indicate that the remedy should reflect the degree of reprehensibility of the representor's conduct, which presumably means the more reprehensible the conduct, the more extensive the relief. In Jennings $v$ Rice ${ }^{24}$ Robert Walker LJ observed that 'the factors relevant to the exercise of the court's discretion' include 'particularly oppressive conduct on the part of the defendant, as in Crabb's case or Pascoe $v$ Turner'. ${ }^{25}$ The idea that misbehaviour or high-handed conduct on the part of the defendant can affect the quantum of relief is also supported by obiter remarks made by Dillon LJ in Burrows $v$ Sharp ${ }^{26}$

${ }^{20}$ Eg Jennings $v$ Rice (n 17); Ottey $v$ Grundy [2003] EWCA Civ 1176 ('Ottey'); Donis v Donis (2007) 19 VR 577 (VSCA).

${ }^{21}$ Eg Sullivan $v$ Sullivan [2006] NSWCA 312. ${ }^{22}$ [2006] EWCA Civ 1139 ('Cobbe').

${ }^{23}$ Ibid [126]. ${ }^{24}$ Jennings $v$ Rice (n 17).

25 Ibid [52] referring to Crabb and Pascoe v Turner [1979] 1 WLR 431 (CA), both of which will be discussed below.

${ }^{26}$ Burrows $v$ Sharp (n 10) 92. 
and Roche LJ in Baker $v$ Baker, ${ }^{27}$ but these remarks were based on what will be shown below to be a questionable reading of comments made by Scarman LJ in Crabb. As Simon Gardner has observed, it is difficult to find authority that directly supports the proposition. ${ }^{28}$ In addition to the obiter dicta, direct support can be found in the form of decisions in which a generous approach to relief coincides with highly reprehensible conduct on the part of the representor. The decision of the Court of Appeal in Cobbe provides one example, although the House of Lords held on appeal that no proprietary estoppel arose on the facts. ${ }^{29}$ The relying party in that case spent considerable time and money seeking planning permission for a property on the assumption that; if the permission was granted, the property would be sold to him on certain agreed terms. As Dyson LJ noted in his discussion of the remedy, the trial judge found that the representor had deliberately refrained from telling the relying party of her change of heart in order to ensure that the relying party 'continued unabated in his efforts to obtain planning permission' which significantly improved the value of the representor's property. ${ }^{30}$ In circumstances in which it was not possible to fulfil or quantify the relying party's expectations or quantify the harm he suffered as a result of his reliance, the Court of Appeal upheld the trial judge's award of an amount equivalent to half of the increase in the value of the property resulting from the grant of planning permission.

A generous approach to relief was also adopted in circumstances involving reprehensible conduct in Pascoe $v$ Turner. ${ }^{31}$ In that case the Court of Appeal held that, even though the defendant's expenditure on improvements was modest, the minimum equity raised by the estoppel required the plaintiff to make good his repeated declaration to the defendant that the house was hers and to transfer the fee simple to the defendant. The plaintiff's conduct might be considered to have been at the highly reprehensible end of the spectrum because he "not only stood by and watched but encouraged and advised, without a word to suggest

27 (1993) 25 HLR 408, 419: 'In determining the relief appropriate the court must look at the conduct of the parties as well as the extent of the equity.'

${ }^{28}$ S Gardner, 'The Remedial Discretion in Proprietary Estoppel' (1999) 115 LQR 438, 454-5.

29 Yeoman's Row Management Ltd v Cobbe [2008] UKHL 55, [2008] 1 WLR 1752. Lord Scott of Foscote nevertheless ag reed with the Court of Appeal that Mrs Lisle-Mainwaring took unconscionable advantage of $\mathrm{Mr}$ Cobbe and Lord Walker of Gestingthorpe described her conduct as 'unattractive' (at [28] and [92] respectively).

${ }^{30}$ Cobbe (n 22) [130]. ${ }^{31}$ Pascoev Turner (n 25) 
that she was putting her money and personal labour into his house'. ${ }^{32} \mathrm{He}$ subsequently sought to evict her from the house 'by any legal means at his disposal with a ruthless disregard of the obligations binding upon conscience'. ${ }^{33}$

Reprehensible conduct by the defendant also coincided with a generous approach to relief in the important case of Crabb. Mr Crabb owned two portions of land, one of which had a right of way giving access to a road and one of which did not. Mr Crabb approached the Council requesting access at a second point so that the two portions could be sold separately. The Council led Mr Crabb to believe that he would be granted a right of way giving access to the back portion and confirmed this assumption by putting up gates at the point of access. In reliance on the assumption $\mathrm{Mr}$ Crabb sold the front portion of his land without reserving a right of way, leaving himself with a landlocked portion. Without knowing that the front portion had been sold, but knowing that Mr Crabb proposed to do this, the Council subsequently took the 'discourteous and high handed' action of pulling down the gates without warning, boarding up the access point and demanding a large sum of money for an easement. The Court of Appeal held that an equity arose against the Council which required the Council to grant a right of way to $\mathrm{Mr}$ Crabb. The court held that, although $\mathrm{Mr}$ Crabb should reasonably have expected to pay for the access, the equity was to be satisfied by requiring the Council to grant the access free of charge. This apparently generous remedy has been seen as a response to reprehensible conduct by the Council. In Jennings $v$ Rice, for example, Aldous LJ accepted as partially correct counsel's argument that the court in $\mathrm{Crabb}$ 'had refused to confine the claimant to his expectations due to the misconduct of the defendant'. ${ }^{34}$ This is the impression given by the judgment in Crabb of Lawton LJ, who had earlier expressed his surprise that a local authority should behave in the way they did, going back on a firm undertaking 'without a word of warning, explanation or apology'. ${ }^{35}$ Lawton LJ appeared to justify the conclusion that the Council should not be paid anything for the right of way on the basis that the Council, 'knowing that the plaintiff intended to sell part of this land, stood by when he did so and without a word of warning allowed him to surround himself with a useless piece of land from which there was no exit'. ${ }^{36}$ The circumstances that led him to agree with Lord Denning MR

32 Ibid 436. ${ }^{33}$ Ibid 438. ${ }^{34}$ Jennings $v$ Rice (n 17) [23].

35 Crabb (n 2) $191 . \quad 36$ Ibid 192. 
that the Council should not be paid anything for the right of way included the fact that:

as the result of the defendants resiling from their undertaking, this piece of land which is designated for light industry has stood useless. It might well have been profitable not only to the plaintiff but to other people living nearby. In an area where employment for the young is not always easy to find, we have the spectacle of this piece of land next door to a housing estate being rendered useless at a time when it could have been of value to the community. For that the defendants are solely to blame. ${ }^{37}$

Lord Denning MR and Scarman LJ, however, clearly justified the remedy solely on the basis that it compensated Crabb for reliance loss he had already suffered as a result of the Council's inconsistent conduct. Lord Denning MR said:

[Mr Crabb's landlocked portion of land] has been sterile and rendered useless for five or six years; and $\mathrm{Mr}$ Crabb has been unable to deal with it during that time. This loss to him can be taken into account. And at the present time, it seems to me that, in order to satisfy his equity, $\mathrm{Mr}$ Crabb should have the right of access at point $B$ free of charge without having to pay anything for it. ${ }^{38}$

In his discussion of what was necessary to satisfy Mr Crabb's equity, Scarman LJ noted that 'had matters taken a different turn' he would without hesitation have said that the plaintiffs should be required to pay a sum of money for the right of way, '[b]ut as already mentioned by Lord Denning MR and Lawton L), there has been a history of delay, and indeed high handedness, which it is impossible to disregard'. ${ }^{39}$ It is this remark that has principally been relied upon in subsequent cases to support the view that the conduct of the parties should be taken into account in the determination of relief..$^{40}$ But it seems clear from what Scarman LJ went on to say in the same paragraph that he reached the conclusion that $\mathrm{Mr}$ Crabb should not be required to pay for the right of way because of the economic harm that the Council's conduct caused Mr Crabb, rather than the moral blameworthiness of that conduct:

I am not disposed to consider whether or not the defendants are to be blamed in moral terms for what they did. I just do not know. But the effect of their action has been to sterilise the plaintiff's land; and for the reasons which I endeavoured to give, such action was an infringement of

${ }^{37}$ Ibid. ${ }^{38}$ Ibid 189-90. ${ }^{39}$ Ibid 199.

40 Especially Burrows v Sharp (n 10) 92 (Dillon LJ) and Baker v Baker (n 27) 419 (Roch LJ). 
an equitable right possessed by the plaintiff. It has involyed him in loss, which has not been measured; but, since it amounted to sterilisation of an ind ustrialestate for a very considerable period of time, it must surpass any sort of sum of money which the plaintiff ought reasonably, before it was done, to have paid the defendants in order to obtain an enforceable legal right. ${ }^{41}$

The reprehensibility thesis derives some support from recent cases in which relief limited to the bare prevention of detriment has been granted in circumstances where the representor's conduct was at the less reprehensible end of the unconscionability spectrum. The decision in Strover $v$ Strover, ${ }^{42}$ which will be discussed in the next section of this chapter, provides one example of this. A second example is Burrows $v$ Sharp, where the representor (Mrs Sharp) promised to bequeath a house to her granddaughter and the granddaughter's husband ( $\mathrm{Mr}$ and Mrs Burrows). In return, the Burrows agreed to provide funding for the acquisition of the house from the local authority and to care for Mrs Sharp's handicapped daughter after Mrs Sharp's death. The plan required the parties to live together in cramped conditions in the house, and this very quickly led to a falling out between them. Dillon LJ described the arrangement as 'a classic example of a good idea which has gone sour without anyone's fault with the result that there has been a major family row and much unhappiness on both sides'. ${ }^{43}$ The trial judge ordered that Mrs Sharp hold the property on trust for herself for life, with remainder to the Burrows. The Burrows were required to continue to make mortgage repayments and the parties were thus required to continue to cohabit. The Court of Appeal held that this was unworkable. Instead, the court held that the equity should be satisfied by Mrs Sharp paying to the Burrows the amount of the mortgage instalments they had paid and their other expenditure on the house, together with interest. It was acknowledged that this remedy would give the Burrows 'nothing for the loss of their expectation that they would succeed to the property 62 Green Way in due course, and nothing for the fact that they have given up security of tenure in their previous flat'. ${ }^{4}$ Dillon LJ, giving the principal judgment, did not directly link the remedy with Mrs Sharp's blamelessness, but did note that the remedy needed to be determined in light of the circumstances at the date of the hearing, taking into account if appropriate conduct of the parties up to that date, including any high-handed conduct of any party'. ${ }^{45} \mathrm{He}$ in fact observed that the

41 Crabb (n 2) 199. ${ }^{42}$ Strover v Strover (n 19).

${ }^{43}$ Burrows v Sharp (n 10) 84. ${ }^{44}$ Ibid 93. ${ }^{45}$ Ibid 92. 
conduct of $\mathrm{Mr}$ and Mrs Burrows, in seeking to enforce a trust deed that made Mrs Sharp a bare trustee of the property for the Burrows, knowing that the deed did not reflect the true agreement between the parties, was 'a factor which comes into consideration under that heading, though in the event I do not think it is a very important factor in this case. ${ }^{46}$

Another good example of limited relief being granted against a relatively blameless defendant is Sullivan $v$ Sullivan ${ }^{47}$ the facts of which were as follows. The appellant was living in a Housing Commission house with her three children. The appellant's brother and sister-in-law told the appellant in a Christmas card that they would purchase a home for her to occupy in return for a small rent. Although the appellant was expected to 'abide by certain basic conditions', it was to be her 'home for life'. The respondents subsequently purchased a house chosen by the appellant and allowed her and her family to live in it for approximately nine years. In reliance on the promise, the appellant gave up Housing Commission accommodation for which she had waited seven years. During her occupancy of the house owned by the respondents the relying party spent some time and effort and the sum of $A U \$ 6,300$ on improvements. The Court of Appeal held by a majority of 2-1 that to hold the respondents to the promise would exceed the requirements of conscientious conduct. The majority held that the equity could be satisfied by allowing the appellant to remain in the house for a further period of seven years subject to the payment of a modest rent. The conduct of the respondents in that case might be considered to be at the less reprehensible end of the spectrum since the original promise was a generous and gratuitous one 'given in the context of an affectionate family relationship, which has since unfortunately broken down'. ${ }^{48}$ Moreover, the respondents had generously given the appellant the benefit of occupation of the house at a low rental for a period of nine years prior to the breakdown of that relationship. ${ }^{49}$

The reprehensibility approach to unconscionability appears, however, to be contradicted by the decision in Jennings $v$ Rice. The relying party in that case ( $\mathrm{Mr}$ Jennings) was a self-employed bricklayer who was initially employed by the representor (Mrs Royle) to work as a gardener in his spare time. Mr Jennings later ran errands, took Mrs Royle shopping and undertook minor maintenance work for her in his evenings and on

46 Ibid. ${ }^{47}$ Sullivan $v$ Sullivan (n 21).

48 Ibid [95]. Counsel for the respondents noted (at [77]) that 'this was a case of pure generosity, not a case where something was done to fulfil a moral responsibility or by way of some trade-off'.

49 Ibid [41]. 
weekends. For the last ten years or so of Mrs Royle's life; this work went unremunerated. As Mrs Royle became infirm in the last few years of her life, $\mathrm{Mr}$ Jennings provided personal care for her and slept on a sofa in her house to provide her with security. Mr Jennings did this work on the faith of assurances that Mrs Royle would 'see him right' and that, 'all this [apparently referring to her house and furniture] will be yours one day'. These assurances were made to Mr Jennings for the very purpose of inducing acts of reliance for Mrs Royle's own benefit. Mrs Royle then deliberately disappointed Mr Jennings' expectations knowing that he had relied on them in a very substantial way over a period of many years. It seemed that Mr Jennings expected to receive at least Mrs Royle's house and furniture (which were worth some $£ 435,000$ ), if not her entire estate (worth $£ 1.285$ million) when she died. Despite the highly reprehensible nature of Mrs Royle's conduct in deliberately inducing substantial acts of reliance for her own benefit and then deliberately breaching her promises, Mr Jennings' equity was assessed by the trial judge at $£ 200,000$, which was the estimated cost of full-time nursing care for the last eight years of Mrs Royle's life, at $£ 25,000$ per year. The Court of Appeal upheld that remedy, which was equal to less than half the value of the house and furniture. Since Mrs Royle's conduct was somewhere near the high end of the reprehensibility scale, the outcome in Jennings $v$ Rice suggests that, if unconscionability plays a role in determining the extent of the remedy granted to give effect to proprietary estoppel, it does not require a generous remedy as a response to highly reprehensible conduct.

\section{The 'extent of responsibility' approach}

Simon Gardner has argued that unconscionability guides the courts in a more specific way, with the quantum of the remedy reflecting the extent of the representor's responsibility for the relying party's assumption and detrimental reliance..$^{50}$ Gardner argues that, while a broader range of factors may legitimately affect the mode of the remedy, the quantum should reflect the aim of the jurisdiction, which is to prevent unconscionable conduct. He suggests that the judge should 'seek the outcome that (in his or

${ }^{50}$ Gardner (n 4) 500. PD Finn, 'Equitable Estoppel' in PD Finn (ed), Essays in Equity (Lawbook Co, Sydney 1985) 92-3 has also argued that the exercise of the remedial discretion in equitable estoppel involves a consideration of 'what, in the circumstances it would be unconscionable for the [representor] to insist upon given the responsibility he bears in or for the [relying party's] actions'. 
her view, though others may differ) best redresses the unconscionability'. ${ }^{51}$ Since the expectation created by the representor and detrimental reliance are the essential ingredients of the unconscionability, 'the outcome must reflect both the claimant's expectation and reliance, and the degree to which these can be ascribed to the defendant, given his encouragement or acquiescence'. ${ }^{52}$ In Gardner's view the remedy should be pitched at some point between the expectation measure and the reliance measure, and that point should be determined by the extent of the representor's responsibility for the expectation and the reliance. On this view, the additional factor raised by the reference to unconscionability is the extent to which responsibility for the expectation and reliance can be ascribed to the defendant.

This view also finds some support in the recent case law. In Strover $v$ Strover Hart J adopted an unusually restrictive approach to relief in circumstances where the representors' responsibility for the relevant assumption was slight. The partners in an accounting firm effected 'mirror policies' of life insurance to protect one another in the event that one of them should die during the life of the partnership. The policies were intended to cover the expense that the surviving partners would incur in having to purchase the partnership interest of the deceased from his estate. Each policy was held on trust, with the two other partners nominated as beneficiaries. One of the partners, the relying party, died after he had retired from the partnership. At the time he retired the relying party wrongly assumed that, following his retirement, the policy would enure for the benefit of his wife and children. In fact the other partners remained the beneficiaries under the trust. In reliance on his false assumption, the deceased lost the opportunity to renegotiate the 'mirror policies' arrangement before he died. The surviving partners would have been likely to agree to correct the arrangement if the matter had been raised with them because they were similarly exposed with their own policies. Hart J concluded that a proprietary estoppel arose in the circumstances, but held that the remedy should reflect the fact that there was a 20 per cent chance that the deceased would not have taken corrective steps had he not been mistaken. The equity arising by way of proprietary estoppel was therefore held to be equal to 80 per cent of the proceeds of the policy. The responsibility borne by the representors in Strover $v$ Strover for the relying party's predicament was clearly at the low end of the spectrum. Not only did the estoppel arise from acquiescence, but the representors shared the

51 Gardner (n 4) 500. ${ }^{52}$ Ibid. 
relying party's mistake. They acquiesced in an arrangement founded on a common mistake, which was that following the relying party's retirement the partnership would maintain the policy at the relying party's expense. ${ }^{53}$ The extremely low level of responsibility borne by the representors might, if one was to adopt the 'extent of responsibility' approach to unconscionability, be said to have justified the unusually strict, reliancebased approach to relief adopted by Hart J. There is no hint of this in the judgment, however, and the outcome can be explained at least as well on the basis of a strict application of the minimum equity principle.

In Murphy $v$ Burrows ${ }^{54}$ the nature of the inducing conduct was expressly acknowledged as an important factor in the determination of relief. The relying party in that case worked part time as a farm hand in the expectation of receiving certain property on the death of the representor. Although it was held that no estoppel arose, the judge said by way of obiter dictum that, if an estoppel had arisen, the remedy should be close to the detriment because of the vague nature of the assurances: 'It seems to me that in all the circumstances of this case, any award should be closer to the detriment suffered by Jimmy Murphy rather than his expectations. I take into account the equivocal nature of the assurances that were made. ${ }^{55}$ He said:

[I]n considering unconscionability in the context of the case as a whole, I do take into account the nature and quality of the assurances that were made. Mr Bragiel in this context relied on the facts in Gillett [ $v$ Holt $]$ as indicating that even vague assurances can found an estoppel. I agree, but I also bear in mind that the quality of the assurances do impact on the issue of unconscionability when looking at the matter 'in the round'. ${ }^{56}$

\section{E. The 'in the round' approach}

A broader interpretation of the unconscionability criterion is that it allows the court, in fashioning the remedy, to take account of all of the circumstances of the case 'in the round'. Nicholas Hopkins has argued that the English courts are developing an approach to remedial discretion in estoppel which requires the judge to evaluate a broad range of factors 'in the round' in order to determine what is necessary to redress the unconscionable conduct. ${ }^{57}$ There is strong support for this view in the

53 Strover v Strover (n 19) [26]-[27], [42]. ${ }^{54}$ [2004] EWHC 1900 (Ch).

55 Ibid [124]. ${ }^{56}$ Ibid [109].

57 N Hopkins, 'Unconscionability, Constructive Trusts and Proprietary Estoppel' in M Bryan (ed), Private Law in Theory and Practice (Routledge-Cavendish, London 2007) 
judgments, ${ }^{58}$ although again it is difficult to identify cases in which it has clearly affected the outcome. In Sledmore $v$ Dalby, ${ }^{59}$ the Court of Appeal held that the Recorder erred by failing to take into account the needs of the parties in determining the appropriate remedy. Sledmore $v$ Dalby provides a very useful example of the issues raised by the 'in the round' approach and will be discussed again later in this chapter. Mr Dalby had made improvements to a house in reliance on an assumption induced by his parents-in-law (Mr and Mrs Sledmore) that the house would one day be given to Mr and Mrs Dalby, and that in the meantime Mr Dalby and his family would be allowed to remain in the house rent free. Mr Sledmore and Mrs Dalby subsequently died, leading to a contest between Mr Dalby and his mother-in-law for the house. At first instance the Recorder held that an equity had arisen in favour of Mr Dalby, which was to be satisfied by Mr Dalby holding a non-assignable personal licence to remain in the property for as long as he wished. The Court of Appeal held that it was no longer inequitable for Mr Dalby's expectation to be defeated and 'the minimum equity to do justice to the respondent ... was an equity which has now expired'. ${ }^{60}$

The outcome in Sledmore $v$ Dalby might have been justified solely on the basis that the respondent had enjoyed eighteen years of rent-free accommodation, and this benefit outweighed the money and labour expended by $\mathrm{Mr}$ Dalby in improving the property in reliance on the assumption. Indeed, Hobhouse LJ did justify the outcome on this basis, ${ }^{61}$ and later in Jennings $v$ Rice Aldous LJ observed that, in Sledmore $v$ Dalby: 'The need for proportionality was at the heart of the judgments. ${ }^{62}$ But Roch LJ, with whom Hobhouse and Butler-Sloss LJJ agreed, held that ' $[t]$ he Recorder should have considered the position of the appellant and her needs and balanced those against the present use of the premises made by the

199, 215. See also N Hopkins, 'Understanding Unconscionability in Proprietary Estoppel' (2004) 20 JCL 210 and N Hopkins, 'Conscience, Discretion and the Creation of Property Rights' (2006) 26 LS 475.

58 In addition to the cases below, it is worth noting that in Baker v Baker (n 27) 419, Roch LJ said: 'The fact that the plaintiff now has suitable accommodation where he has good neighbours and is very happy should not deprive him of relief, but is a factor which should be taken into account by the court in seeking the minimum equity to do justice in this case.' See also J Mee, 'The Limits of Proprietary Estoppel: Thorner v Major' (2009) 21 CFLQ 367, 376.

59 (1996) 72 P \& CR 196 (CA) 204. ${ }^{60}$ Ibid 205.

61 Ibid 209. Hobhouse LJ also held that the assumption on which Mr Dalby incurred the expenditure was that Mrs Sledmore would leave the property to her daughter, and this assumption was never falsified.

62 Jennings $v$ Rice (n 17) [29]. 
respondent and his present need for them'. ${ }^{63}$ Roch LJ treated as significant the fact that Mr Dalby was making minimal use of the house at the time of the trial and had accommodation elsewhere. His elder daughter had married and his younger daughter, at the age of 27, was 'able to maintain herself' ${ }^{64}$ Mrs Sledmore, on the other hand, was in a precarious financial position, was 'liable to lose her present accommodation and ... has a pressing need' to use the house 'for occupation as her own residence. ${ }^{65}$ Although the outcome might have been justified on the basis of an approach that looked only at what was the minimum necessary to ensure that $\mathrm{Mr}$ Dalby suffered no detriment, the weight placed on the relative needs of the parties for the subject property makes Sledmore $v$ Dalby a leading example of the 'in the round' approach.

Another prominent example of the 'in the round' approach is Jennings $v$ Rice, which was discussed earlier. In that case the trial judge treated as relevant his views that the representor had no special obligations to her family, that to reward an employee on the scale of $£ 420,000$ was excessive, that the house was an unsuitable one for the relying party to live in, and that Mr Jennings would need $£ 150,000$ to buy a suitable house. ${ }^{66}$ The Court of Appeal accepted these as relevant considerations. Aldous LJ, with whom Mantell and Robert Walker LJJ agreed, held that the value of the equity 'will depend on all of the circumstances' and that the trial judge 'took into account the relevant factors as placed before him, namely the expectation, the detriment, the position of Mr Jennings and the amount available'. ${ }^{67}$

An additional factor that might be relevant to the 'in the round' approach was mentioned by way of obiter by Robert Walker LJ in Jennings $v$ Rice. Robert Walker LJ observed that, where a proprietary estoppel arises out of a consensual arrangement between the parties falling short of a binding contract, 'then the court's natural response is to fulfil the claimant's expectations' ${ }^{68}$ Robert Walker LJ was referring to a situation in which the action taken by the relying party was seen by the parties as a quid pro quo for the relevant promise, and this took the form of a mutual understanding which identified both 'the expected detriment and the expected benefit' in reasonably clear terms. In those circumstances, Robert Walker LJ suggested, the court is inclined 'to vindicate the claimant's expectations as far as possible' because the parties 'probably regarded the expected benefit and the accepted detriment as

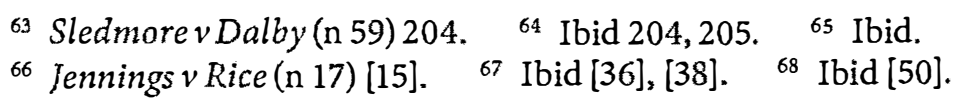


being (in a general, imprecise way) equivalent, or at any rate not obviously disproportionate'. ${ }^{69}$ In Jennings $v$ Rice, neither the expected detriment nor the expected benefit were defined in clear terms by the parties, so the suggested principle did not apply in that case. The idea has been strongly criticized $^{70}$ and, in subsequent extra-judicial writing, Robert Walker has accepted that he 'would have done better to refer to a spectrum rather than a dividing line' since there is rarely 'anything like a clear bargain at the outset of the relationship. ${ }^{71}$ The status of the principle is therefore in some doubt.

The reasoning of the New South Wales Court of Appeal in Sullivan $v$ Sullivan also provides strong support for a broad 'in the round' approach. The facts of the case were discussed above. The New South Wales Court of Appeal held (2-1) that the loss of the public housing was a significant detriment, but had not adequately been quantified by the relying party. The relying party had led no evidence as to how long it would take her to regain public housing. The majority noted that, although 'prima facie the operation of estoppel is to preclude departure from the assumed state of affairs', that entitlement is qualified if such relief would 'exceed the requirements of conscionable conduct and would be unjust to the estopped party'. ${ }^{72}$ The majority held that it would be unjust to enforce the promise in this case because:

(1) the promise was gratuitous, given in the absence of any substantial moral obligation or any kind of trade off;

(2) the promise was given in the context of an affectionate family relationship, which has unfortunately since broken down;

(3) the appellant is now about 40, so has a life expectancy that could be of the order of 40 years;

(4) $\ldots$ an order that bound the respondents for up to a further 40 years could work significant hardship if their financial circumstances change;

(5) all this must be considered in light of the paucity of evidence referred to earlier, which should not operate in favour of the appellant. ${ }^{73}$

69 Ibid [45].

70 Gardner (n 4) 494-7; J Mee, 'The Role of Expectation in the Determination of Proprietary Estoppel Remedies' in M Dixon (ed), Modern Studies in Property Law (Vol 5) (Hart Publishing, Oxford 2009) 389, 411-15.

71 R Walker, 'Which Side "Ought to Win": Discretion and Certainty in Property Law' (2008) 6 TQR 5, 10; also published in [2008] Sing JLS 229, 239.

72 Sullivan $v$ Sullivan (n 21) [94]. ${ }^{73}$ Ibid [95]. 
In all of those circumstances, the relying party's equity was held to be satisfied by an order that allowed the relying party to remain in the house for a further seven years. Allowing the relying party to remain in the house for seven years was said to provide the relying party with a reasonable time to seek suitable Housing Commission accommodation, although the court could not conclude that it was 'likely to be sufficient for her to obtain such accommodation'. ${ }^{74}$ The majority therefore granted a remedy that was designed to give the relying party an opportunity to resume her pre-reliance position. This was a reliance-based remedy, although it was not entirely certain to protect the relying party against reliance loss. This limited relief was justified by a range of factors considered in the round, which included the gratuitous nature of the promise, the non-reprehensible nature of the representors' conduct and the potential hardship to the representors if they were made to fulfil the promise. The dissenting judge in Sullivan $v$ Sullivan, Handley JA, applied the principles from Giumelli v Giumelli ${ }^{75}$ and Jennings $v$ Rice and concluded that it was not inequitably harsh to enforce the relying party's expectations of accommodation for life. Handley JA held that the representors had not discharged the evidentiary onus of bringing forward material to cut down the relying party's prima facie entitlement. ${ }^{76}$

Whether it is relevant to the exercise of the remedial discretion that a promise is gratuitous and made in the absence of any prior moral obligation or trade off is now a contentious question in Australian law. In his dissenting judgment in Sullivan $v$ Sullivan, Handley JA observed that estoppels by encouragement have frequently been upheld in the absence of a prior moral obligation. ${ }^{77}$ The Victorian Court of Appeal in Donis $v$ Donis ${ }^{78}$ preferred the view of Handley JA in Sullivan $v$ Sullivan to that of the majority, holding that it was irrelevant that the promises in Donis $v$ Donis were gratuitous and given in the absence of a moral obligation. The equity arising by way of estoppel does not, Nettle JA said, require a trade off or consideration, but 'inheres in the detriment which

74 Ibid [96]. $\quad{ }^{75}$ Giumelli v Giumelli (n 11)

76 On the onus question, the approach of Handley JA is undoubtedly correct. To establish the estoppel, the onus on the claimant is to show that she will suffer substantial detriment if the assumption is not adhered to. Once substantial detriment is established, the onus shifts to the representor to show that the detriment can be prevented in some way other than by holding the representor to the assumption. Given the difficulty of quantifying detriment in most cases, the doctrine of proprietary estoppel would operate very differently from the way it does if the onus were on the relying party to quantify his or her detriment.

77 Sullivan v Sullivan (n 21) [54]. ${ }^{78}$ Donis v Donis (n 20). 
the promisee suffers by acting in reliance upon the promise. ${ }^{79}$ Nettle JA said that a lack of moral obligation is only relevant in limited circumstances: 'where the meaning of a promise or assurance is uncertain, a lack of existing moral obligation may reveal that the plaintiff's expectation or assumption is extravagant and thus that equity is better satisfied in another and more limited way'. ${ }^{80}$ In other words, the lack of a trade off or moral obligation goes to the extravagance or unreasonableness of the assumption adopted by the relying party. Proprietary estoppel will only protect the relying party to the extent that his or her assumptions and acts of reliance are reasonable, and whether an assumption is reasonable depends on the circumstances in which it was induced. ${ }^{81}$ The maximum remedy, therefore, is fulfilment of the relying party's reasonable expectations ${ }^{82}$ and an extravagant expectation cannot in any circumstances be protected.

In Jennings $v$ Rice, Robert Walker LJ suggested that 'it would be unwise to attempt any comprehensive enumeration of the factors relevant to the exercise of the court's discretion' in giving effect to an equitable estoppel. It may well be contrary to the spirit of the 'in the round' approach even to attempt to list the major factors. Nevertheless, it seems that the principal factors that might be taken into account include the following, in addition to the uncontroversial criteria set out in the second section of this chapter. If the 'in the round' approach is accepted as good law then the court not only can have regard to these factors but perhaps ought, for consistency, to do so in an appropriate case. First, the court can have regard to any misconduct or high-handed conduct on the part of the representor. Second, the court can take account of any misconduct on the part of the relying party. ${ }^{83}$ Third, the court can have

79 Ibid [40] (Nettle JA, with whom Maxwell ACJ and Ashley JA agreed).

80 Ibid [41] (emphasis added).

81 The leading authority on this point is now Thorner $v$ Major [2009] UKHL 18, [2009] 1 WLR 776 (noted by B McFarlane and A Robertson, 'Apocalypse Averted: Proprietary Estoppel in the House of Lords' (2009) 125 LQR 535 and Mee (n 58)).

82 See Wormall $v$ Wormall [2004] EWCA Civ 1643 and A Robertson, 'Reasonable Reliance in Estoppel by Conduct' (2000) 23(2) UNSWLJ 87, 97-8.

83 In Jennings $v$ Rice (n 17) [52], Robert Walker LJ suggested that the factors relevant to the exercise of the court's discretion include misconduct on the part of the claimant. The case cited in support of this proposition was J Willis \& Sons $v$ Willis [1986] 1 EGLR 62 (CA) (' $J$ Willis'), a straightforward unclean hands case in which claimants who had submitted a fraudulent document in support of their claim were denied relief. Cf Gonthier $v$ Orange Contract Scaffolding Ltd [2003] EWCA Civ 873 ('Gonthier') criticized by M Halliwell, 'Equitable Property Rights, Discretionary Remedies and Unclean Hands' [2004] Conv 439, 449-51. 
regard to the present and future financial needs of the parties including, where appropriate, the extent of other claims on the representor's estate. Fourth, the court can have regard to the fairness and appropriateness of any exchange between the parties. This includes an objective element such as that taken into account by the trial judge in Jennings $v$ Rice; ie whether the promise was an appropriate one in the context of the relationship between the parties. The assessment of the fairness of the exchange may also include a subjective element, so that where the assurances have 'a consensual character falling not far short of an enforceable contract' then it is relevant that the parties themselves 'regarded the expected benefit and the accepted detriment as being (in a general, imprecise way) equivalent'. ${ }^{84}$ While the court might be inclined to grant full expectation relief in the 'near contract' situation, the fact that the promise was entirely gratuitous and given in the absence of an existing moral obligation, in a case such as Sullivan $v$ Sullivan, might incline the court towards more limited relief.

\section{F. The limits of unconscionability}

The discussion above has shown that the 'reprehensibility', 'extent of responsibility' and 'in the round' approaches to unconscionability all find some support in the case law. The 'in the round' approach has the strongest support, although the outcomes of the cases that are commonly cited in support of that approach can mostly be explained on other bases. The cases in which relief has been refused to a relying party who has engaged in misconduct can mostly be justified on the basis of the 'clean hands' defence. ${ }^{85}$ Cases in which relief has been limited to something less than complete fulfilment of expectations, and in which this outcome might be attributed to a consideration of unconscionability 'in the round' factors, can mostly be rationalized on the basis of the proportionality principle. ${ }^{86}$ Cases in which a generous remedy has been granted against a representor who has engaged in high-handed conduct can mostly be rationalized on the basis that this was the only way to ensure that the relying party suffered

84 Jennings $v$ Rice (n 17) [45].

${ }^{85}$ Notably $J$ Willis (n 83) and Gonthier (n 83). See also Williams $v$ Staite [1979] Ch 291 (CA) 299 where Goff LJ (with whom Cumming Bruce LJ agreed) accepted in obiter that an equity arising by way of proprietary estoppel can be lost through misconduct, but explained this as an application of the clean hands doctrine.

${ }^{86}$ Notably Burrows v Sharp (n 10); Sledmore v Dalby (n 59) 204; Campbell v Griffin [2001] EWCA Civ 990; Strover v Strover (n 19); Sullivan v Sullivan (n 21); Donis v Donis (n 20). 
no detriment ${ }^{87}$ It would be difficult to argue that authority compels the 'reprehensibility', 'extent of responsibility' or 'in the round' approach to be followed. It remains to consider the difficulties, in principle and in application, with those different approaches to unconscionability.

In a proprietary estoppel case, departure from the relevant assumption is only unconscionable if, inter alia, the departure would cause harm to the relying party as a result of action he or she has taken in reliance on the assumption. ${ }^{88}$ If that is so, then once the detriment has been avoided, there can be nothing unconscionable in the representor acting inconsistently with the assumption. That is why the choice of remedy in proprietary estoppel cases focuses on what is necessary to prevent detriment resulting from reliance. ${ }^{89}$ Introducing the representor's level of responsibility, the reprehensibility of his or her conduct or other conscience-based factors into the remedial equation must necessarily have the effect of either overcompensating or undercompensating the relying party. There can be no justification for either. In order to do justice to the relying party, the courts must ensure that the remedy is adequate to prevent detriment and, in order to do justice to the representor, the courts must ensure that the remedy goes no further than is necessary to prevent detriment. Thus, in Jennings $v$ Rice, Robert Walker LJ said that: 'The essence of the doctrine of proprietary estoppel is to do what is necessary to avoid an unconscionable result, and a disproportionate remedy cannot be the right way of going about that. ${ }^{\prime 90}$

Two examples from the recent case law show that courts cannot respond to the degree of responsibility at the same time as ensuring both that the relying party suffers no detriment and that the remedy is proportionate to the detriment. The first example is Munt $v$ Beasley, ${ }^{91}$ where a tenant improved a loft space on the assumption that the loft space was included in the lease. The landlord acquiesced in that work while being

87 Notably Crabb (n 2). A possible exception is Pascoev Turner (n 25), although the outcome of that case might perhaps be explained on the basis that the relying party had, as a result of reliance on the relevant assumption, developed a significant emotional attachment to the house in question and would have suffered a substantial emotional detriment if she had been forced to make a new home elsewhere: see Robertson (n 6) 309-12.

88 This point is made repeatedly in the case law. See eg, Ottey (n 20) [54] where Arden LJ observed that: 'In the course of his judgment, Robert Walker LJ [in Gillett $v$ Holt] by implication accepted the argument that what makes an assurance binding is the detrimental reliance on the promise by the person to whom the assurance is given (see [2001] Ch 210 at 227).'

${ }^{89}$ See Robertson (n 6) 302-3. 90 Jennings $v$ Rice (n 17) [56].

9. [2006] EWCA Civ 370. 
mistaken as to his own legal rights. The court concluded that fulfilment of the relying party's expectation would not be disproportionate to the reliance loss arising from the renovation work. It could be concluded that in this case the representor's responsibility for the assumption was slight, as it was in Strover $v$ Stover, because he was mistaken as to his own legal rights and confirmed the relying party's assumption only through acquiescence. It was not possible, however, to weigh that level of responsibility against both the need to protect against reliance loss and the need to go no further than is necessary to do so. The degree of responsibility could only be factored in by undercompensating the relying party.

In Ottey $v$ Grundy, ${ }^{92}$ on the other hand, the relevant assumption was induced by an express promise which was confirmed in writing. The unequivocal nature of the assurance might, in accordance with the extent of responsibility approach, have justified a generous remedial outcome, but there was no room for it to play a role in the determination of relief. The need to ensure proportionality between the remedy and the detriment required a remedy that was less than half the value of the expectation. If the high degree of responsibility borne by the representor was to be factored into the remedial equation, this could only be doneby departing from the minimum equity principle and granting a disproportionate remedy. This could be justified only if the remedial goal was to punish the representor.

These two examples show that the extent of the representor's responsibility cannot be factored into an equation that requires the court to ensure both that the relying party is protected against harm and that the remedy goes no further than is necessary to prevent harm. The extent of responsibility can play a role in the determination of relief only if the court rejects both the proportionality principle and the principle that the remedy must provide complete protection against harm. The 'reprehensibility' and 'in the round' approaches to unconscionability face the same difficulty: the considerations they introduce can be accommodated only by undercompensating or overcompensating the relying party.

The 'in the round' approach to unconscionability suffers from two additional problems. The first is that the 'in the round' approach introduces at the remedial stage factors that do not relate to the reason for intervention, or basis of the equity. The basis of the equity is the representor's responsibility for ensuring that no harm is suffered by the relying party, as a result of his or her reliance, as a consequence of the 
representor's inconsistent behaviour. ${ }^{93}$ As a matter of principle, the remedy should reflect that reason for intervention, and factors that have no relation to the basis of liability should not affect the quantum of relief. ${ }^{94}$ The second problem is that the factors are not applied consistently. Not only is there obvious scope for disagreement as to the relevance of a particular factor, but it seems that some 'in the round' considerations, such as the financial needs of the parties and whether an excessive reward was promised for services performed by the relying party, play a role only in cases involving family members and domestic carers. ${ }^{95}$ In proprietary estoppel cases arising between parties at arm's length, the courts consistently assess how best to satisfy the equity by reference to a more tightly constrained set of criteria. In such cases the courts look only to the relying party's expectations, the nature of the relying party's detriment, the need for proportionality and how best to achieve it. ${ }^{96}$ Many proprietary estoppel cases concern dealings between parties at arm's length. In these cases the courts do not take account of broader considerations such as the needs of the parties or the appropriateness of the relevant promise. ${ }^{97}$ There can be no justification for treating the remedial question in cases

93 This point is made by S Bright and B McFarlane, 'Proprietary Estoppel and Property Rights' [2005] CLJ 449, 463-5 and McFarlane (n 4) 460.

94 Gardner (n 28) 459-60; Gardner (n 4) 501 ('As a matter of principle, the quant um of relief ought to be affected only by factors germane to the recipe by which a claim arises at all').

95 A similar point about the application of settled principles, rather than resort to fairness and unconscionability, in the determination of the commercial cases was made by B McFarlaneand D Nolan, 'RemedyingReliance: The Future Development of Promissory and Proprietary Estoppel in English Law' (Obligations III Conference, University of Queensland, July 2006).

96 A rare exception to this is Cobbe (n 22), where the Court of Appeal may have taken the reprehensibility of the representor's conduct into account.

97 Some recent examples are: Scottish \& Newcastle plc v Lancashire Mortgage Corporation Limited [2007] EWCA 684, [56]-[57] (dealings between creditors concerning the priority of charges); Bexley London Borough Council v Maison Maurice Ltd [2006] EWHC 3192, [72]-[74] (dealings between landowners concerning access to property); McKeand $v$ Thomas [2006] NSWSC 1028, [2006] NSWSC 1356 (dealings between neighbours concerning licence to run service cables through one property to the neighbouring property); Strover $v$ Strover (n 19) [41]-[45] (dealings between partners in an accounting firm concerning interests in a life insurance policy); Sweet $v$ Sommer [2004] EWHC 1504 (Ch) [42]-[43] (dealings between owners of adjoining property concerning a right of way); Hypec Electronics Pty Ltd $v$ Mead [2003] NSWSC 934, aff'd [2004] NSWCA 221 (dealings between liquidator and company director); Heggies Bulkhaul Ltd $v$ Global Minerals Pty Ltd [2003] NSWSC 851 (dealings between tenant and purchaser of land); O'Brien $v$ Sheahan [2002] FCA 1292 (dealings between trustee in bankruptcy and bankrupts); Roufeil v Lusby [2003] NSWSC 1002 (dealings between liquidator and company directors). 
between family members and those involving domestic carers as turning on different considerations from those that are applied in cases arising between parties acting at arms' length, such as neighbours in dispute over a right of way or secured creditors involved in a priority dispute. If it was appropriate in Jennings $v$ Rice to take account of the fact that $£ 420,000$ was an excessive reward for an employee, then consistency would require the court also to consider the appropriateness of promises and the fairness of exchanges in proprietary estoppel cases between parties at arm's length. If the financial needs of the parties are relevant to the determination of the extent of an equity arising by way of estoppel in a domestic case, it is difficult to see why that consideration is not equally relevant to the determination of the extent of an equity arising in a commercial case. If the equity arising by way of proprietary estoppel in the commercial cases is the same as that arising in the family property cases, then the same set of criteria should be applied to determine the appropriate relief.

The case of Sledmore $v$ Dalby exemplifies the problems identified above. If, as Hobhouse LJ found, the expense and effort incurred by Mr Dalby in improving the property were outweighed by the benefit of eighteen years of rent-free accommodation, then there was no room for the needs of the parties to play a role in the determination of the remedy. If Mr Dalby's financial or housing needs were greater than those of his mother-in-law, it is difficult to see how this could justify the granting of a remedy to him if he suffered no net detriment as a result of his reliance on the assumption. A remedy for Mr Dalby could be justified only on the basis that it would be unconscionable for Mrs Sledmore to turn Mr Dalby out of the house because he was in financial need. That financial need would have no connection to the equity arising by way of estoppel (assuming it did not result from Mr Dalby's reliance on the promise) and could therefore be justified only on the basis of a broader principle that it is unconscionable to assert a property interest against a person in greater need. ${ }^{98}$

If, on the other hand, the benefits received by Mr Dalby did not adequately compensate him for the effort and expenditure he incurred, then it is difficult to see how his equity could be extinguished by Mrs Sledmore's need for accommodation. Mrs Sledmore's obligation not to cause harm by behaving inconsistently would somehow then be

98 As McFarlane (n 4) 460 observes, the court would be taking advantage of the parties' presence before it to adjust their rights according to 'some abstract notion that rights relating to land should be distributed according to people's need', which not only does not relate to the basis of the claim before the court, but does not form part of the broader system of land law. 
qualified by a counter-obligation on the part of Mr Dalby not to assert an equity against a person in greater need. The refusal of relief in specie to Mr Dalby could perhaps be justified on the basis of hardship as a discretionary bar to the granting of specific relief, but if that were so, the decisive influence on the remedy would be better understood as an application of more broadly applicable equitable principles relating to hardship rather than a principle specific to proprietary estoppel.

\section{G. Conclusion}

Where a proprietary estoppel is established, the representor's conscience requires that the relying party's reliance interest is adequately protected, through fulfilment of the relevant assumption, through adequate compensation or some other remedy. Because reliance loss commonly takes the form of unquantifiable harm, in many cases the only way to ensure that the relying party is fully protected against reliance loss is to require the representor to adhere to the relevant assumption. But once the relying party is adequately protected against reliance loss, the representor's conscience is assuaged. A remedy that exceeds the minimum necessary to ensure complete protection against reliance loss goes beyond the requirements of good conscience and is unjust to the representor. These considerations properly balance the interests of the relying party and the representor, and properly focus the court's attention on the reasons for intervention. They leave no scope for factoring in the reprehensibility of the representor's conduct, the nature of the inducing conduct or broader 'in the round' considerations which are unconnected with the basis of the equity arising by way of proprietary estoppel. 


\section{University Library}

\section{- M M I N E R VA A gateway to Melbourne's research publications}

Minerva Access is the Institutional Repository of The University of Melbourne

Author/s:

Robertson, A

Title:

Unconscionability and proprietary estoppel remedies

Date:

2010-01-01

Citation:

Robertson, A. (2010). Unconscionability and proprietary estoppel remedies. Bant, E (Ed.). Harding, M (Ed.). Exploring Private Law, (1), pp.402-426. Cambridge University Press.

Persistent Link:

http://hdl.handle.net/11343/30227 